\title{
Inovasi Bupati di Ruang Demokrasi: Upaya Membangun Kesadaran Inovasi Birokrasi
}

\author{
Bambang Widiyahseno•
}

\begin{abstract}
Decentralization and granting broad autonomy to the local government open the space for the continuity of policy innovation. This study is important because not all regional heads could do it. There are many parties involved and interested in the process. This study explores the behavior of regents to build awareness and mindset (unfreezing) to various parties. The magnitude of opportunities to innovate is largely determined by regent ability to perform the process of unfreezing. The findings indicate a regent's effort in building relationships with various parties, especially the power of the bureaucracy, parliament and society (the public) in the process of unfreezing ie melting of the ice or the awareness of the need for change (innovation). Those are Strategies to encourage and initiate innovation to anticipate the bureaucracy, which is building a coalition with the community to deal with the inert bureaucracy.
\end{abstract}

\section{Keywords:}

innovation; power relations; unfreezing.

\begin{abstract}
Abstrak
Desentralisasi dan pemberian otonomi yang luas kepada pemerintah daerah membuka ruang bagi berlangsungnya inovasi kebijakan. Studi ini penting dilakukan mengingat tidak semua kepala daerah bisa melakukannya. Ada banyak pihak yang terlibat dan berkepentingan dalam proses tersebut. Kajian ini menelusuri perilaku bupati untuk membangun kesadaran dan pola pemikiran (unfreezing) kepada berbagai pihak. Besarnya peluang melakukan inovasi sangat ditentukan oleh kemampuan bupati melakukan proses unfreezing. Hasil temuan menunjukkan adanya upaya bupati dalam membangun relasi kuasa dengan berbagai pihak khususnya birokrasi, DPRD, dan masyarakat atau publik dalam proses unfreezing, yaitu pencairan dari kebekuan atau penyadaran tentang perlunya perubahan atau inovasi. Strategi untuk mendorong dan menginisiasi inovasi adalah dengan menyiasati birokrasi, yaitu membangun koalisi dengan masyarakat untuk menghadapi birokrasi yang lembam.
\end{abstract}

\section{Kata Kunci:}

inovasi; relasi kekuasaan; unfreezing.

\section{Pendahuluan}

Persoalan daerah semakin kompleks, tidak bisa diselesaikan dengan cara biasa melainkan

\footnotetext{
- Alumni S3 Ilmu Politik, FISIPOL, Universitas Gadjah Mada, Yogyakarta,

Email: bbwidiyahseno@yahoo.com
}

dibutuhkan cara-cara yang sama sekali berbeda dengan sebelumnya, salah satunya dengan inovasi (Martin FIMM., 1998; Bekkers, 2005). Desentralisasi dan pemberian otonomi yang sangat luas kepada pemerintah daerah, secara tidak langsung menjanjikan adanya (jika bukan maraknya) inovasi. Demikian pula 
dengan demokratisasi, masyarakat semakin menuntut sikap tanggap atau proaktif dari pemerintah untuk menyelesaikan berbagai permasalahan, salah satunya dengan inovasi. Studi ini mencoba mendalami dinamika ruang berinovasi, dipergunakan oleh kepala daerah yang menjabat di era otonomi daerah dan demokratisasi, yang memiliki komitmen tinggi untuk berinovasi. Telaah akademik tentang hal ini sangat urgent mengingat sederetan kepala daerah yang telah berjuang berinovasi pada akhirnya justru dipersalahkan.

Secara yuridis, ruang untuk berinovasi memang terbuka lebar. Setelah reformasi yang diikuti dengan kebijakan desentralisasi yang luas, termaktub dalam UUD 1945 Pasal 18 ayat 1- 6 dan UU Nomor 23 Tahun 2014, hak daerah untuk mengatur dan mengurus rumah tangganya sendiri tidak hanya dijamin, melainkan juga diperluas cakupan dan kedalamannya. Pemerintah daerah, melalui kepala daerahnya memiliki kewenangan serta keleluasaan yang lebih besar untuk melakukan berbagai upaya secara kreatif untuk membangun dan memajukan daerah demi menyejahterakan masyarakat melalui berbagai inovasi.

Hal yang perlu dikaji secara seksama, sebenarnya bukan hanya apakah momentum ini dimanfaatkan oleh para kepala daerah dalam menggulirkan berbagai inovasi saja, namun yang lebih penting dalam proses inovasi adalah menyangkut tingkat penerimaan perubahan sebagai konsekuensi adanya inovasi, sehingga inovasi dapat berlangsung. Urgensi untuk menakar peluang berinovasi tidak mudah, mengingat inovasi biasanya ditelaah dalam kerangka pikir ekonomis semata. Perhatian utamanya pada pemanfaatan produk, bukan perubahan tatanan pemerintahan. Ketika perhatian terfokus pada produk, maka inovasi terlihat sebagai cerita sukses dari eksploitasi gagasan baru (Mitra, 2001 dan the British Council, 2000 dalam Taufiq, 2007). Inovasi memang terkait dengan penciptaan hal yang baru, dan tidak mengherankan jika perbincangan tentang inovasi selama ini lebih dipahami sebagai persoalan 'kebaruan' dari pada persoalan 'penerimaan' perubahan (Beck and Whistler, 1967 dalam Osborne dan Brown, 2005; Jawa Pos Pro Otonomi, 2011).

Kecenderungan ini seakan menutupi kenyataan bahwa, apa yang dianggap baru dan diputuskan terbaik bagi inovator belum tentu baik dan dapat diterima oleh sebagian pihak lain. Sisi kebaruan lebih dikedepankan, sehingga keberlanjutan inovasi tidak terantisipasi dengan baik. Tidak dapat dipungkiri bahwa inovasi menyangkut pengembangan proses, fungsi, manfaat, sikap dan perilaku yang berbeda dengan sebelumnya. Perubahan-perubahan tersebut akan terjadi jika kepentingan dari berbagai pihak dapat diakomodasi dan dipertemukan. Telaah populer tentang inovasi tersebut secara taken for granted adalah inovasi dengan serta-merta akan menghasilkan tatanan sistemik yang mapan.

Ketika membahas inovasi dalam penyelenggaraan pemerintahan daerah di era otonomi daerah, yang justru penting untuk ditelaah adalah perubahan sistemiknya, bukan semata-mata produk inovasi itu sendiri. Oleh karena itu, dalam kajian ini, inovasi dipahami sebagai perubahan tatanan dalam pemerintahan daerah yang kemudian mengakibatkan perubahan sistemik, baik menyangkut sistem kerja, sistem pelayanan, sistem perizinan, sistem pengelolaan tenaga kerja dan sebagainya. Setiap individu dan kelompok terkait bahkan memiliki kepentingan terhadap sistem. Perlu dipastikan bahwa adanya tatanan sistemik"menjebak" para aktor untuk berperilaku dengan pola tertentu. Studi ini tidak bermaksud mengikari kenyataan bahwa inovasi senantiasa terkait dengan kebaruan. Hanya saja perhatian berlebih pada sisi kebaruan, ditambah inovasi yang tidak berkelanjutan membuat studi tentang inovasi kehilangan relevansinya.

Pengkajian inovasi dari sisi hasil perubahan sistemik sangat diperlukan 
mengingat adanya konteks makro yang membingkainya. Pengembangan inovasi di era otonomi daerah berlangsung simultan dengan proses demokratisasi. Proses ini memberi ruang bagi munculnya berbagai aktor (multistakeholders) untuk terlibat dalam berbagai kebijakan (Pratikno, 2004; 2007). Momentum demokrasi juga memberi kesempatan bagi munculnya berbagai kekuatan, baik di tingkat lokal maupun nasional, untuk melakukan intervensi terhadap berbagai inovasi. Dalam alam demokrasi, inovasi merupakan kreasi bersama dari berbagai aktor. Pemimpin atau kepala daerah yang memiliki visi inovator harus bisa memosisikan diri sebagai fasilitator dalam proses inovasi. Inovator harus mampu menjalin relasi antara berbagai aktor agar inovasinya dapat diterima. Di balik perubahan sistemik tersebut ada proses-proses politik yang seringkali tidak banyak diperhatikan. Politik di sini didefinisikan sebagai relasi kekuasaan yang dipraktikkan dalam ranah kepentingan publik.

Menurut Lewin (1951) untuk melakukan perubahan inovasi harus melalui tiga tahapan yaitu unfreezing, changing, dan refreezing. Tujuan utama kajian ini adalah menelusuri perilaku bupati untuk membangun kesadaran dan pola pemikiran (unfreezing) kepada berbagai pihak. Hal ini mengingat pihak yang merasa nyaman dan diuntungkan akan berusaha menentang dan mempertahankan sistem lama. Lewin (1951) menyatakan bahwa proses unfreezing sangat penting dan menentukan keberhasilan proses selanjutnya.

\section{Proses Inovasi dalam Kelembaman Sistemik}

Studi ini dilakukan dengan asumsi bahwa proses inovasi kebijakan menghadapi kelembaman sistemik. Hal ini terjadi karena inovasi dipandang sekadar perubahan teknis prosedural yang bersifat administratif, tentang tata cara pelaksanaan semata dan bukan bersifat politis, yang bertujuan membongkar sistem lama dan membangun sistem baru. Dalam proses tersebut ada pihak-pihak yang merasa terganggu kepentingannya. Penulis mengacu pada konsep Lewin (1951), bahwa inovasi senantiasa berlangsung dalam tatanan sistemik. Melakukan inovasi pada dasarnya adalah melangsungkan perubahan sistemik itu sendiri. Lewin (1951) menyederhanakan perubahan sistemik ke dalam tiga tahapan: (1) unfreezing, (2) changing, dan (3) refreezing.

Unfreezing, merupakan suatu proses penyadaran tentang perlunya, atau adanya kebutuhan untuk berubah. Changing, merupakan langkah tindakan, baik memperkuat (driving force) maupun memperlemah (resistences), sehingga proses perubahan dapat berlangsung. Refreezing, membawa kembali organisasi kepada keseimbangan yang baru (a new dynamic equilibrium). Dalam kajian ini, perubahan sistemik terjadi dalam ruang demokrasi. Oleh karenanya banyak pihak yang bermain dan memiliki berbagai kepentingan terhadap inovasi. Bupati, dengan otoritas dan kewenangan yang dimilikinya, dituntut untuk mampu memberikan ruang bagi mereka yang terlibat agar tercapai kesepakatan, sehingga inovasi dapat diterima. Demi memperluas ruang berkembangnya inovasi, bupati dituntut untuk mampu menggunakan kekuasaannya dengan menjalin relasi kuasa antar berbagai pihak terkait, baik langsung ataupun tidak langsung.

\section{Aktor dalam Perubahan Sistemik}

Tulisan ini bermaksud memperlakukan inovasi sebagai bagian tak terpisahkan dari perubahan sistemik, tanpa bermaksud mengingkari poin penting dari tradisi kajian manajemen, yang bersifat teknokratis. Pada konteks ini inovasi bukanlah perubahan yang terjadi secara alamiah, melainkan dirancang serta dikehendaki oleh inovator yaitu bupati. Sehingga tetap saja dibayangkan bahwa perubahan merupakan dampak dari tindakan aktor dan bekerjanya force-field. Perubahan 
terjadi adanya kekuatan-kekuatan penekan dari lingkungan (Lewin, 1951). Tekanantekanan terhadap organisasi, individu, atau kelompok yang berlangsung secara terus menerus memantik hadirnya perubahan.

Senantiasa ada dua kekuatan dalam perubahan, yaitu kekuatan untuk mendorong perubahan (driving forces) dan kekuatan untuk menentang perubahan (restraining forces). Masing-masing datang dari berbagai pihak yang memiliki kepentingan terhadap perubahan akibat manusia. Kekuatan pendorong datang dari kelompok yang menghendaki adanya perubahan, sedangkan kekuatan penentang biasanya datang dari kalangan yang takut akan kegagalan, kehilangan status, terbiasa dengan kemapanan (settle) yang telah dirasakan, dan kekurangan sumber daya atau sumber penghasilan. Apabila kekuatan pendorong lebih besar atau setidaknya seimbang, maka sedikit demi sedikit perubahan akan terjadi. Akan tetapi jika kekuatan penentang lebih kuat maka perubahan tidak akan terjadi.

Lewin(1951)menyatakanbahwa aktoryang terlibat dalam perubahan bisa saja hadir sebagai kelompok. Artinya, perubahan merupakan permainan antarkelompok pendorong dan penentang. Kelompok pendorong adalah yang memiliki kepentingan dan harapan yang sama dengan inovator, sedangkan kelompok penentang bisa saja merupakan kelompok yang memiliki kepentingan atau harapan yang berbeda dengan inovator atau juga yang merasa terusik bahkan dirugikan dengan adanya inovasi.

Dalam pandangan Lewin, tidak ada pihak ketiga yang terlibat dan memiliki kemampuan menghentikan efek dari inovasi. Pihak ketiga seolah-olah tidak muncul untuk menengahi proses pertentangan antarakelompok atau yang sengaja melakukan perubahan. Perubahan seolah terjadi secara alamiah sebagai pertarungan kalah-menang antarkelompok. Hal tersebut merupakan kelemahan dari penjelasan Lewin. Padahal ada kemungkinan pihak ketiga muncul untuk memanfaatkan pertentangan dua kubu. Dalam sistem politik pun, elemen pertentangan akan semakin kompleks, bukan sekadar dua kelompok kepentingan namun banyak kepentingan yang terlibat. Mempertimbangkan keterbatasan dari tesis Lewin ini, maka studi ini mengantisipasi adanya pihak ketiga, seperti aktor intelektual yang sengaja melakukan perubahan atau tidak.

\section{Memperluas Ruang Inovasi dengan Menjalankan Kekuasaan}

Aktor kunci inovasi dalam suatu institusi biasanya adalah pemimpin (Burns, 1979; Skogen, 1997; Horth, 2005). Sebagai pemimpin, seseorang memiliki kekuasaan yang dapat memberi ruang bagi berkembangnya inovasi. Pemimpin sebagai inovator memiliki kepentingan agar inovasinya dapat berhasil, sehingga kewenangan yang dimiliki dapat dipergunakan untuk mencapai tujuannya. Dimensi ruang menjadi penting mengingat keberhasilan inovasi tidak diukur dari sisi kebaruannya melainkan tingkat penerimaan dari berbagai aktor dan keberlanjutannya (Hinning, 1963). Upaya yang dilakukan untuk menciptakan ruang bagi berkembangnya inovasi adalah dengan memainkan berbagai pihak yang terlibat (Ann Glynn, 1996). Pemimpin berusaha mendorong berbagai pihak untuk berperan dalam inovasi dengan cara mempraktikkan kekuasaan yang dimiliki (Pelz, dkk.,1980; Ann Glynn, 1996).

Dengan kekuasaan yang dimilikinya, inovator berkeinginan dapat melakukan perubahan-perubahan inovatif. Pada konteks ini, inovasi adalah proses politik (Martin FIMM, 1998). Dalam arti luas, politik adalah suatu usaha yang dilakukan untuk mempengaruhi pihak lain agar mau mengikuti atau menerima keinginannya dengan cara-cara, taktik atau strategi tertentu (Budiardjo, 1991). Sebagai suatu dimensi yang menekankan pada tindakan, Foucault (1981) mengatakan kekuasaan ada 
di mana-mana yang berada di ruang publik. Kekuasaan manifest dalam bekerjanya strategi. Kekuasaan, dengan demikian adalah praktik yang terjadi dalam suatu ruang lingkup tertentu.

Terdapat banyak posisi yang secara strategis berkaitan satu dengan yang lain dan senantiasa mengalami pergeseran (Foucault, 1981). Foucault (1981) mengatakan kekuasaan menentukan susunan, aturan, dan hubungan dari dalam. Sejalan dengan hal itu, kekuasaan bertautan dengan pengetahuan yang berasal dari relasi-relasi kekuasaan yang menandai subjek (Foucault dalam McHoul, 2002). Kajian ini mengambil pelajaran dari Foucault yang menekankan eratnya pertautan antara kekuasaan dengan pengetahuan. Kekuasaan akan memberikan ruang bagi berkembangnya pengetahuan tentang inovasi dan memproduksi pengetahuan, juga sebaliknya yaitu menyediakan kekuasaan.

Mengacu pada Foucault (1972) yang mengaitkan kekuasan dengan pengetahuan, studiini memperlakukan kepemimpinan sebagai praktik kuasa-menguasai. Pemimpin yang memiliki pengetahuan dapat memosisikan diri sebagai seorang inovator dan berkesempatan menyisipkan kepentingan di balik inovasi yang diusungnya. Oleh karena itu, sebagai seorang pemimpin, ia akan berusaha membangun relasi kuasa dengan yang dipimpin. Pemimpin harus mempraktikkan kekuasaannya agar kepentingan inovasi dapat berhasil, diakui, dan diterima oleh pihak lain (Ann Glynn, 1996). Untuk itu pemimpin akan berusaha mempengaruhi pihak lain.

Pemimpin dituntut untuk piawai dalam menghadapi begitu banyak orang yang dipimpinnya. Sehingga ia akan membangun relasi kuasa dengan berbagai pihak yang dipandang nyaman dalam penguasaannya, agar inovasinya dapat berhasil (Bains, 2009). Karakteristik inovasi yang demikian menunjukkan inovasi sebagai sebuah proses politik. Kepemimpinan, mau tidak mau melibatkan permainan kekuasaan sehingga kepentingannya terwujud, dan inovasi menjadi bagian dari tatanan sistemik yang berlaku. Dalam konteks ini, inovasi kebijakan melibatkan relasi kuasa yang dipraktikkan di sepanjang proses inovasi itu (Borins, 2008). Relasi kuasa yang berlangsung tidak hanya berwatak represif namun bisa juga konstruktif-solutif dan akomodatif, yang pada saat bersamaan dapat menyediakan titik temu antarkepentingan agar inovasinya dapat diterima dan berlanjut terus (sustainable dan terinstitusionalisasi).

Demi kesuksesan inovasinya, pemimpin perlu menegosiasikan berbagai kepentingan tersebut, hingga ditemukan titik sepakat antara keinginan pemimpin dan perubahan. Oleh karenanya seorang pemimpin perlu memiliki driving force. Di sinilah urgensi mengaktualisasikan kepemimpinan inovatif yaitu kreatif, visioner dan solutif, yang sebetulnya ditentukan oleh derajat perubahan yang hendak diwujudkan (Pratikno, 2009). Semakin mendasar perubahan yang hendak dilakukan, semakin besar pula urgensi untuk mengaktualisasikan kepemimpinan inovatif yang menguasai konteks (Grindle, 1997). Dengan demikian upaya untuk memperluas ruang berkembangnya inovasi menjadi semakin penting. Usaha yang dilakukan oleh pemimpin untuk memperluas ruang inovasi adalah dengan menjalankan kewenangan yang dimiliki yaitu dengan jalan mempraktikkan relasi kekuasaan dengan berbagai pihak.

MenurutFreiden(2000) untukmenganalisis proses kebijakan dalam ekonomi politik (dalam modern political economy) paling tidak ada empat langkah teoretis, yaitu: 1) mengidentifikasi aktor, tujuan, dan kepentingannya masingmasing. 2) Menggambarkan preferensi masing-masing aktor mengenai kebijakan yang menangani suatu isu. 3) Menguraikan bagaimana para aktor membangun relasi demi mencapai tujuan. 4) Mendeskripsikan interaksi para aktor dengan berkoalisi kepada lembagalembaga sosial lainnya. 


\section{Metode Penelitian}

Fokus dari kajian ini adalah menelusuri praktik inovasi yang dilakukan oleh Bupati Untung Wiyono di Kabupaten Sragen selama dua masa jabatan yaitu mulai tahun 2001 2011. Penelusuran ini menyangkut: Bagaimana upaya yang dilakukan bupati untuk melakukan proses unfreezing, dengan sub masalah yaitu: 1) siapa saja aktor-aktor yang terlibat, 2) apa tujuan dan kepentingan masing-masing aktor tersebut, 3) bagaimana relasi antar-aktor dalam proses unfreezing?

Analisis dilakukan dalam fase unfreezing dengan menelusuri dua bidang inovasi yaitu inovasi kebijakan dalam pelayanan perizinan terpadu dan pelayanan dalam pemerintahan dengan menerapkan program IT (electronic government/e-gov). Kajian ini merupakan penelitian kualitatif yang bersifat deskriptif dan eksploratif, yaitu mendeskripsikan dan menggali secara terbuka, diikuti dengan menginterpretasikan secara objektif (Vredenbrug., Jacob, 1986), berbagai fenomena yang menyangkut proses-proses inovasi kebijakan yang dilakukan Bupati Untung Wiyono. Penelitian ini melacak praktik inovasi yang dilakukan Untung Wiyono dalam membuka ruang untuk keberhasilan inovasi. Studi ini juga menelusuri upaya Untung Wiyono dalam menjalin relasi kekuasaan terhadap berbagai pihak, yaitu publik, untuk membangun inovasi kebijakan.

Penelitian ini membutuhkan data sekunder berbentuk dokumen resmi pemerintah seperti beberapa Peraturan Daerah, Keputusan dan
Peraturan Bupati, berbagai dokumen terkait sistem kebijakan baru, visi dan misi Kabupaten Sragen, berita-berita media massa, dokumen yang dikeluarkan LSM, biografi, wawancara elite lokal oleh media massa, artikel para analis, buku-buku dan sebagainya melalui library research. Data primer juga digunakan yaitu berupa hasil wawancara dengan para informan yang diperoleh dengan wawancara mendalam (indepth interview).

Informan ditentukan menggunakan metode snowball sampling, sehingga membuka jalan peneliti untuk lebih lengkap mengungkap fenomena. Informan penelitian ini ada 66 orang meliputi para pejabat birokrasi (29 orang) mulai dari Bupati, Sekda, Kepala Dinas, Kepala Badan Pelayanan Perizinan Terpadu beserta staf, Kepala Kantor Pusat Data Elektronik (PDE) berserta staf, anggota DPRD (26 orang), tokoh dan masyarakat yang dirasa paham dengan masalah inovasi kebijakan (11 orang) yang terdiri dari masyarakat yang berurusan dengan pelayanan tersebut, para stakeholders terkait, aktivis LSM, wartawan, tokoh organisasi massa, akademisi, mahasiswa, dan tokoh agama.

Untuk menganalisis data sekunder dan primer di atas, penulis menggunakan dua metode yaitu triangulasi dan interpretatif. Metode triangulasi digunakan untuk memeriksa keabsahan data dengan memanfaatkan sesuatu yang lain di luar data itu, untuk keperluan pengecekan atau pembanding. Analisis interpretatif digunakan untuk memahami atau memaknai data (fenomena) dan membangun argumen-argumen konseptual (teoretis) yang

Tabel 1.

Jumlah Informan Sesuai Kelompoknya, Pihak Pro dan Kontra dengan Bupati

\begin{tabular}{lcccc}
\hline & $\begin{array}{c}\text { Birokrat/ } \\
\text { eksekutif }\end{array}$ & DPRD & $\begin{array}{c}\text { Masyarakat/ } \\
\text { Tokoh }\end{array}$ & Jumlah \\
\hline Pro Bupati & 22 & 17 & 4 & 43 \\
Kontra Bupati & 7 & 9 & 7 & 23 \\
\hline Jumlah & 29 & 26 & 11 & 66 \\
\hline
\end{tabular}

Sumber: Diambil dan diolah dari data informan 
abstrak. Analisis dilakukan dalam konteks makro maupun mikro dengan menelusuri tujuan dan kepentingan dari para aktor atau stakeholder terlibat. Dua kasus di bidang inovasi yang dianalisis yaitu inovasi pelayanan perizinan terpadu (BPPT) dan inovasi birokrasi melalui e-government.

\section{Strategi Menyadarkan dengan}

\section{Mempertemukan Tujuan dan Kepentingan}

\section{Upaya Untung Wiyono dalam Proses}

Unfreezing

Agar terjadi unfreezing, Untung Wiyono menerapkan strategi kepada para birokrat dengan memberikan harapan dan iming-iming jabatan bagi yang mendukung, begitupun sebaliknya sebaliknya. Hal ini memiliki implikasi politik yaitu munculnya kelompok yang mendukung dan yang menolak. Dalam proses ini terjadi tarik ulur kepentingan di antara berbagai pihak terkait. Melalui pendekatan ekonomi-politik maka masingmasing aktor akan berusaha memaksimalkan kepentingannya. Masing-masing berusaha untuk mendekati dan menjalin relasi sebaik mungkin dengan bupati.. Untung Wiyono dalam melakukan pencairan (unfreezing) sangat tergantung pada tingkat keberhasilan menemukan titik kesamaan atau titik temu pandangan, antara inovator dengan berbagai pihak terkait. Ciri utama dalam fase unfreezing adalah terjadinya perubahan pandangan dari berbagai pihak terhadap gagasan inovasi.

Berdasarkan hasil penggalian data, tujuan dan kepentingan secara umum dari masingmasing aktor terhadap inovasi sebagai proses perubahan dalam fase unfreezing dapat dilihat dalam Tabel 2.

Dari Tabel 2 terlihat bahwa masingmasing pihak memiliki tujuan dan kepentingan yang berbeda yang akan memberikan implikasi politik dalam mempraktikkan inovasi. Di satu sisi, akibat tujuan dan kepentingan yang berbeda-beda tersebut terjadilah proses saling menyiasati demi mencapai tujuan. Mereka berusaha saling mempengaruhi, menjalin relasi dengan memaksimalkan kepentingan dan manfaat dari inovasi. Melihat kondisi tersebut, konsolidasi kepentingan sangat

Tabel 2.

Tujuan dan Kepentingan Masing-Masing Aktor terhadap Inovasi sebagai Proses Perubahan dalam Fase Unfreezing

\begin{tabular}{|c|c|c|}
\hline Aktor & Tujuan & Kepentingan \\
\hline $\begin{array}{l}\text { Bupati (Untung } \\
\text { Wiyono) }\end{array}$ & $\begin{array}{l}\text { Berbagai pihak dapat mengetahui } \\
\text { dan sadar pentingnya mengubah pola } \\
\text { pemikiran (mengubah mindset) }\end{array}$ & $\begin{array}{l}\text { Diakui berhasil membangun Sragen, dapat dipilih } \\
\text { kembali dan anak-anaknya dapat melanjutkan } \\
\text { kepemimpinannya. }\end{array}$ \\
\hline Birokrat & Dapat mengetahui pentingnya inovasi & Dapat bekerja secara lebih baik dan nyaman \\
\hline DPRD & Dapat mengetahui tentang inovasi & $\begin{array}{l}\text { Mendapatkan massa/suara agar dapat terpilih } \\
\text { kembali sebagai anggota DPRD }\end{array}$ \\
\hline Pengusaha & $\begin{array}{l}\text { Proses-proses yg bersentuhan dengan } \\
\text { birokrasi dapat cepat, mudah, dan murah }\end{array}$ & $\begin{array}{l}\text { Mendapatkan pelayanan yang baik, perizinan } \\
\text { mudah, usahanya lebih lancar. }\end{array}$ \\
\hline $\begin{array}{l}\text { Tokoh } \\
\text { masyarakat, } \\
\text { masyarakat }\end{array}$ & $\begin{array}{l}\text { Mengetahui dan memahami tentang } \\
\text { pentingnya perubahan }\end{array}$ & $\begin{array}{l}\text { Sragen lebih maju, lebih baik, dapat meningkatkan } \\
\text { kesejahteraan masyarakat. }\end{array}$ \\
\hline $\begin{array}{l}\text { Pemerintah } \\
\text { Pusat }\end{array}$ & $\begin{array}{l}\text { Ditemukan sebuah model tata kelola } \\
\text { kepemerintahan daerah yang lebih baik }\end{array}$ & $\begin{array}{l}\text { Dapat memberikan pelayanan yang efektif, efisien, } \\
\text { meningkatkan kesejahteraan masyarakat. }\end{array}$ \\
\hline Media Massa & $\begin{array}{l}\text { Mencari tokoh inovator dalam era } \\
\text { demokrasi dan otonomi daerah } \\
\text { sebagaimana yang diharapkan oleh } \\
\text { sponsor yaitu lembaga-lembaga donor } \\
\text { internasional }\end{array}$ & $\begin{array}{l}\text { Menjadi media yang mengikuti trend dan berpihak } \\
\text { pada kepentingan publik. Mendapat support dari } \\
\text { lembaga donor internasional. }\end{array}$ \\
\hline
\end{tabular}

Sumber: Diolah dari hasil wawancara dengan informan dan berbagai data sekunder. 
diperlukan. Strategi yang dilakukan Untung Wiyono adalah mempertemukan tujuan dan kepentingan dengan mempraktikkan relasi kuasa terhadap berbagai pihak agar inovasi dapat berhasil. Strategi yang dilakukan Untung Wiyono terlihat dalam Tabel 3.

Sebagaimana terlihat pada Tabel 3, secara umum Untung Wiyono mengawali proses unfreezing pada masa jabatan pertama, ketika pasangan bupati ini masih dipilih melalui anggota DPRD. Ia telah memulai proses unfreezing dengan menyampaikan gagasan perubahan sejak dilantik sebagai kepala daerah tahun 2001. Ia menyampaikan dalam pidato sambutan, dihadapan para anggota DPRD Sragen tentang perlunya perombakan besarbesaran dalam sistem kerja pemerintah daerah, jika Sragen ingin maju dan dikenal (Sumber: naskah pidato Untung Wiyono; Wawancara dengan Untung Wiyono; Meletakkan Pondasi Pembangunan Daerah: Wiyono, 2010). Dalam melakukan perubahan ia mulai dengan menjalin relasi dengan orang-orang dari kelompok terdekat yaitu DPRD, PDIP, Golkar dan para birokrat (Wiyono, 2006).

Dalam masa jabatan pertamanya, Untung Wiyono belum memiliki visi dan misi yang jelas. Namun karena pengalaman serta wawasannya yang luas di bidang usaha, ia memiliki kesan tersendiri menyangkut birokrasi, yaitu sebuah pengalaman yang serba sulit dan berbelit-belitjika berhubungan dengan urusan birokrasi. Untuk itu langkah awal yang ia tempuh dalam masa jabatan pertama ini adalah mewacanakan akan dilakukannya reformasi birokrasi melalui inovasi di bidang pelayanan. Kabupaten Sragen jika ingin maju dan mengharap para investor datang serta bersedia menginvestasikan modalnya, harus

Tabel 3.

Tujuan, Kepentingan dan Upaya Bupati Mempraktikkan 'Relasi Kuasa' dengan Berbagai Aktor agar Proses Unfreezing dapat Berlangsung dalam Inovasi

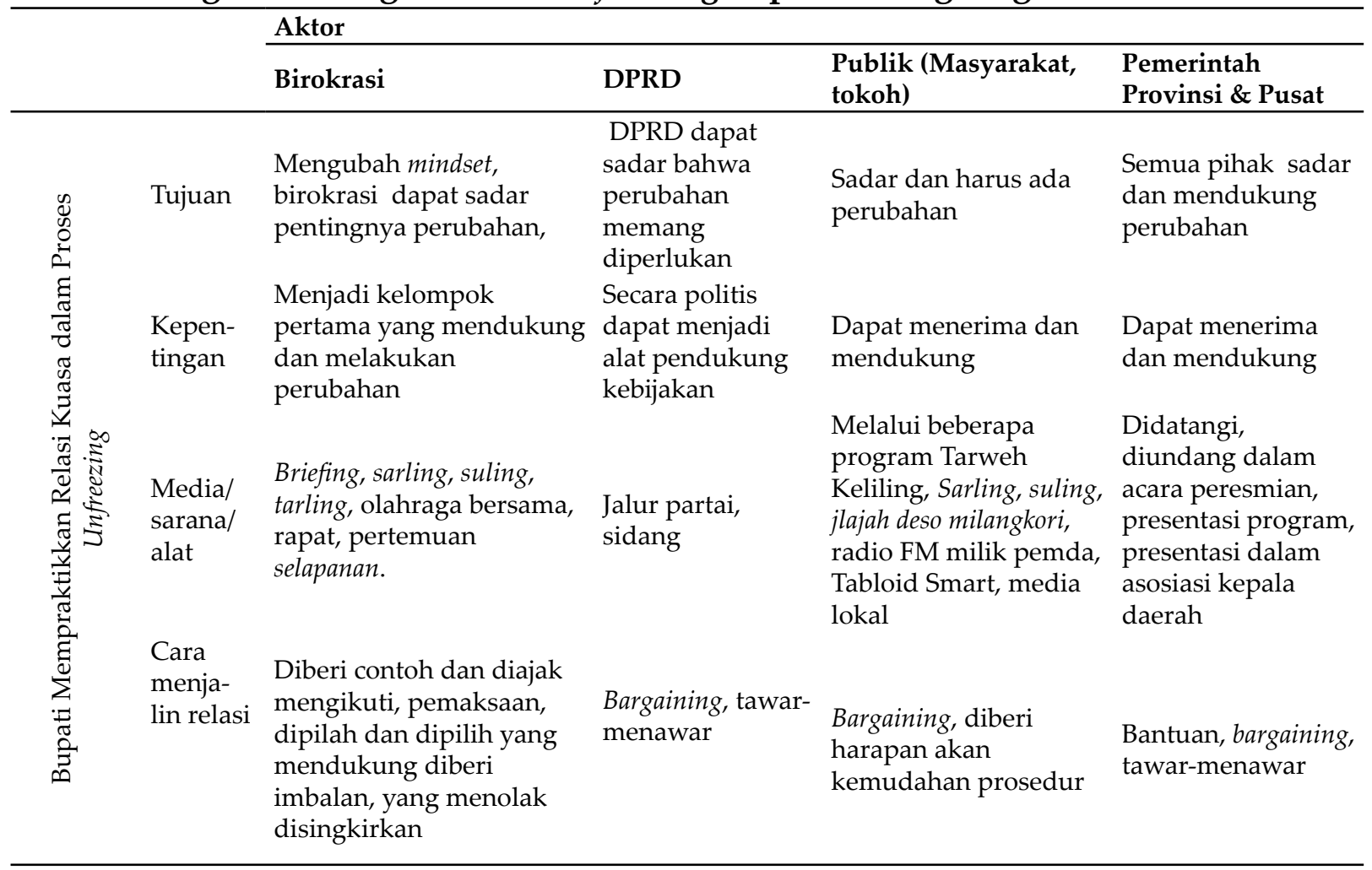

Sumber: Diolah dari hasil wawancara dengan informan dan berbagai data sekunder serta buku Untung Wiyono 
berani mengawali diri dengan memberi jaminan pelayanan yang baik, perizinan yang mudah, cepat dan transparan (Wawancara dengan Untung Wiyono, 31-07-2010).

Untuk melakukan reformasi birokrasi, menurut Untung Wiyono, dimulai dengan mewacanakan perlunya mengubah mindset birokrat yaitu dari yang minta dilayani menjadi melayani masyarakat (Wiyono;, 2010: 86). Jika sebelumnya aparat birokrasi minta dilayani, setelah reformasi sekaligus demokratisasi aparat harus segera melakukan perubahan. Hal ini untuk menyikapi era globalisasi, berbagai pihak bisa masuk dan bebas mempengaruhi suasana yang makin kompetitif. Jika aparat birokrasi tidak berani memulai dari sekarang maka akan semakin sulit dan terdesak (Untung Wiyono. Meletakkan Pondasi Pembangunan Daerah: hal. 7-16; ungkapan ini juga sering ia sampaikan sewaktu peneliti mengikuti bupati melakukan kunjungan ke daerah/desa).

Walaupun begitu Bupati menyadari betul bahwa untuk membangun mindset dengan melakukan perubahan tidaklah mudah, akan banyak terjadi resistensi, sedangkan jika ingin maju dan berkembang harus berani. Terlepas dari berbagai kontroversi, bupati berusaha selalu mewacanakan adanya perubahan, yaitu ajakan mengubah sikap dan perilaku untuk mendekati masyarakat dan melayani mereka dengan baik, dalam rangka meningkatkan kesejahteraan mereka sendiri. Menurut Untung Wiyono, seorang pemimpin dalam kepemimpinanya adalah menyangkut kekuatan daya tahan secara psikologis, dalam mempertahankan prinsip dan keinginannya dengan yang dipimpin. Hal terpenting adalah tujuannya baik dan demi masyarakat sehingga pemimpin harus tetap maju (Wawancara dengan Untung $\mathrm{W}, 18-08-2010$ ). Jika pemimpin kalah atau menyerah pada keadaan maka tidak akan mampu melakukan perubahan. Oleh karena itu ia tidak henti-hentinya mengajak dan mendorong reformasi birokrasi melalui perubahan cara melayani.
Wacana akan dilakukannya perubahan disampaikan terus-menerus dalam berbagai forum. Salah satunya dilakukan dalam briefing yang dilaksanakan setiap bulan sekali pada hari Senin minggu pertama. Saat pertemuan pertama disampaikannya gagasan, muncul sedikit tanggapan dari beberapa kepala dinas yang merasa akan diambil lahanya, namun posisi mereka tidak bisa berbuat apapun. Mereka menyatakan bahwa hal itu merupakan kewenangan bupati, mereka menyerahkan kepada bupati jika akan dilakukan perubahan dan itu lebih baik.

Strategi yang dilakukan bupati untuk memobilisasi wacana adalah mengajak mereka studi banding ke daerah yang telah berhasil melakukan perubahan (benchmarking)seperti Pare-Pare, Padang Pariaman dan juga ke Kabupaten Gianyar Provinsi Bali. Dari hasil studi banding tersebut, para kepala dinas diajak diskusi tentang alternatif terjadinya perubahan. Setelah mengkaji nilai positif dan negatifnya mereka setuju melakukan perubahan dengan tujuan untuk kemajuan Kabupaten Sragen (Wawancara dengan Mahmudi, 18-8-2010)

Untung Wiyono mengajak para birokrat (Kepala Dinas, Kepala SKPD, Kepala Bagian) untuk mengikuti berbagai acara bupati dalam berkunjung berdialog dengan masyarakat melalui acara sambang deso dan jajah deso milangkori, acara suling, sarling, tarling, maupun acara ndalang. Melalui berbagai acara tersebut Untung Wiyono mengajak, memberi nasihat, motivasi untuk mendengarkan suara keluhan dan permintaan masyarakat. Penulis berkalikali mengikuti acara tersebut, masyarakat dirasa sangat antusias menyampaikan berbagai persoalan serta tuntutan adanya perubahan pelayanan dari birokrasi.

\section{Memecahkan Kebekuan: Strategi Memaksa Birokrasi untuk Berubah dengan Memanfaatkan Tuntutan Publik}

Proses unfreezing Inovasi Pelayanan Perizinan Terpadu (BPPT) terjadi mulai 
tahun 2001-2002. Tujuan dan kepentingan dari masing-masing aktor terhadap inovasi pelayanan perizinan terpadu dalam fase unfreezing terlihat pada Tabel 4.

Tujuan dan kepentingan dari masingmasing aktor sebagaimana terlihat dalam Tabel 4 berbeda-beda. Melihat kondisi tersebut, strategi relasi kekuasaan yang dilakukan Untung Wiyono, untuk menemukan titik temu kepentingan di antara mereka yaitu dengan mengkonfrontasi antara keinginan dan kepentingan masyarakat, dengan pandangan para birokrat.

Dalam era teknologi tinggi, publik menuntut semuanya serba cepat, tepat serta hemat biaya. Mindset tentang sistem pelayanan yang cepat, tepat, dapat terukur baik dari sisi waktu dan biaya ini banyak berkembang di masyarakat, sehingga tuntutan akan modelmodel pelayanan seperti ini sangat tinggi. Jika pemerintah daerah, yang telah diberi otonomi tidak bisa mengubah dirinya untuk berkreasi melakukan berbagai inovasi maka akan dikecam oleh masyarakat pengguna. Apabila birokrasi, sebagai unsur utama pelaksana kebijakan pelayanan, tidak mengubah paradigmanya dari minta dilayani menjadi melayani secara responsive, maka akan berhadapan dengan keinginan masyarakat.
Suasana reformasi, otonomi daerah, demokratisasi serta globalisasi semakin menguatkan masyarakat untuk menuntut inovasi kebijakan menyangkut pelayanan publik, khususnya di bidang pelayanan perizinan. Kelompok masyarakat yang paling vokal menuntut perubahan pelayanan adalah LSM Forum Masyarakat Sragen (Formas) dan LSM Lingkar Kajian Kebijakan dan Strategi Perubahan Sragen (Lintas) yang dipimpin Saiful Hidayat. Sedangkan tokoh masyarakat di lembaga sosial keagamaan yang paling vokal menuntut perubahan adalah dari Pimpinan Daerah Muhammadiyah, termasuk kalangan Pemuda Muhammadiyah (Wawancara dengan Saiful Hidayat, Senin 15 Mei 2010, pukul 09.0011.30).

Momentum tersebut betul-betul dimanfaatkan oleh Untung Wiyono untuk memecahkan kebekuan. Di samping dalam kepemimpinannya menghendaki adanya perubahan melalui inovasi, dan publik juga menghendaki adanya perubahan, maka untuk mewujudkannya ia menjalin relasi dengan mereka untuk melawan para birokrat yang masih tetap bertahan dengan keinginan status quonya. Berikut runtutan peristiwa dari relasi pertentangan tersebut:

Tabel 4.

Tujuan dan Kepentingan Masing-Masing Aktor terhadap Inovasi Pelayanan Perizinan Terpadu dalam Fase Unfreezing

\begin{tabular}{lll}
\hline Aktor & Tujuan & Kepentingan \\
\hline $\begin{array}{l}\text { Bupati (Untung } \\
\text { Wiyono) }\end{array}$ & $\begin{array}{l}\text { Berbagai pihak dapat sadar } \\
\text { pentingnya melakukan perubahan } \\
\text { sistem pelayanan perizinan. }\end{array}$ & $\begin{array}{l}\text { Diakui berhasil membangun Sragen melalui pelayanan } \\
\text { perizinan. Untung Wiyono dapat dipilih kembali menjadi } \\
\text { bupati. }\end{array}$ \\
DPRD & $\begin{array}{l}\text { Dapat bekerja secara nyaman } \\
\text { Mendapatkan jabatan, insentif, tambahan pendapatan. } \\
\text { Ikut menumpang popularitas }\end{array}$ & $\begin{array}{l}\text { Mendapat massa/suara agar dapat terpilih lagi sebagai } \\
\text { anggota DPRD }\end{array}$ \\
Pengusaha & $\begin{array}{l}\text { Proses-proses yang bersentuhan } \\
\text { dengan birokrasi dapat cepat, } \\
\text { mudah, dan murah }\end{array}$ & $\begin{array}{l}\text { Mendapatkan pelayanan yang baik, perizinan mudah, } \\
\text { usahanya lebih lancar. }\end{array}$ \\
$\begin{array}{l}\text { Tokoh } \\
\text { masyarakat, } \\
\text { masyarakat }\end{array}$ & Sistem regulasi yang lebih baik \\
$\begin{array}{l}\text { Pemerintah } \\
\text { Pusat }\end{array}$ & $\begin{array}{l}\text { Ditemukan sebuah model tata } \\
\text { pelayanan yang lebih baik }\end{array}$ & $\begin{array}{l}\text { Bupati, birokrasi dapat melayani masyarakat dengan lebih } \\
\text { baik. Sragen lebih maju, lebih baik, dapat meningkatkan } \\
\text { kesejahteraan masyarakat. }\end{array}$ \\
\hline
\end{tabular}

Sumber: Diolah dari informasi yg diperoleh dari data primer dan sekunder 
Untung Wiyono menjadi Bupati Sragen periode I pada bulan Mei tahun 2001. Pada saat itu, pelayanan satu atap telah dilaksanakan sejak tahun 1995 dengan landasan hukum Undang-Undang Nomor 9 Tahun 1995 tentang Usaha Kecil. Namun sistem pelayanan satu atap ini dirasa belum efektif memberikan kemudahan, kelancaran, kecepatan, dan kepastian dalam pelayanan. Hal ini dikarenakan dalam pengurusan perizinan masih melalui jalur yang panjang sehingga tidak semuanya dapat diselesaikan di satu tempat. Di Sragen sistem pelayanan satu atap ini tidak bisa berjalan efektif, bahkan dihapuskan mulai tahun 1999 dan kembali menggunakan sistem konvensional yaitu kembali ke dinas atau Satuan kerja (Satker) masing-masing, yang berlangsung sampai tahun 2001.

Pada awal diberlakukannya pelayanan satu atap yang digagas oleh bupati sebelumnya, Bawono, banyak terjadi pertentangan dari berbagai kalangan baik dinas maupun masyarakat pengguna. Dari sisi dinas, dianggap mengurangi lahan penghasilan mereka, sedangkan bagi masyarakat sistem itu dianggap masih sulit, tidak efektif, dan efisien baik dari kecepatan waktu maupun biaya. Oleh karena itu akhirnya ditetapkan kembali lagi ke sistem konvensional (Wawancara dengan Saiful Hidayat, Senin 15 Mei 2010, pukul 09.00-11.30). oleh karenanya, kembalinya sistem pelayanan ke Satker disambut baik oleh aparat birokrasi di dalam dinas, karena menjadi lahan penghasilan bagi dinas atau aparat yang bersangkutan.

Di sisi lain, tuntutan dari berbagai pihak khususnya yang terkait dengan berbagai perizinan cukup tinggi. Mereka menuntut agar birokrasi mampu melayani dengan lebih baik, terutama setelah reformasi dan demokratisasi. Sayangnya, saat itu Bupati Bawono tidak dapat berbuat banyak karena masa jabatannya akan segera berakhir. Kondisi semacam inilah yang disebut freezing (beku), sebagaimana digambarkan oleh Lewin (1951) bahwa ada berbagai pihak yang berusaha mengunci dan mempertahankan sistem lama, yang dianggap bisa menjamin keuntungan bagi dirinya. Saat itupun Bupati Bawono tidak memiliki kepentingan dan ambisi untuk melakukan perubahan, ditambah lagi para aparatur birokrasi ingin mempertahankan sistem yang ada.

Ilustrasi kondisi freezing di atas menunjukkan begitu kuatnya keinginan untuk mempertahankan sistem lama, yang dianggap sudah nyaman dan menguntungkan bagi dinas atau Satker. Masing-masing dinas atau Satker menunjukkan keegoisannya untuk mempertahankan perizinan tersebut demi penghasilan tambahan.

Bupati terpilih dalam pemilihan tahun 2001 yaitu Untung Wiyono tampaknya memahami betul hal itu. Satu-satunya kunci yang dimanfaatkan untuk membuka kebekuan tersebut diawali dengan momentum reformasi dan demokratisasi, berbagai pihak menghendaki adanya perubahan. Momentum saja tidak cukup dan tetap harus diikuti langkah yang pasti. Hal itu bisa dimulai dari membentuk kepemimpinan kuat untuk berani mewacanakan tuntutan stakeholders dan masyarakat terhadap kinerja birokrasi agar melayani dengan semakin baik.

Strategi yang dilakukan Untung Wiyono cukup berani dan keras, yaitu menarik semua bentuk perizinan setelah melalui berbagai sosialisasi dan studi banding ke daerah lain. Untung mengajak para birokrat mengunjungi masyarakat untuk mendengarkan keluhan dan memahami permintaan mereka. Strategi ini dilakukan sejak awal masa jabatannya di periode pertama. Oleh karena itu, pewacanaan rencana inovasi telah dilakukan pula sejak awal melalui ceramah-ceramah oleh Untung sendiri, saat berlangsung acara Subuh Keliling (Suling), Ashar Keliling (Sarling), Tarweh Keliling (Tarling) ataupun acara seperti Sambang Desa, Jlajah Deso Milang Kori dan acara Dalang.

Semua acara tersebut harus diikuti oleh para pimpinan birokrat, bahkan Sambang Deso 
dan Jlajah Deso Milang Kori harus diikuti semua pegawai pemda yang ada di Sragen. Sejak Untung Wiyono menjabat, khususnya dalam masa jabatan periode pertama, para birokrat lebih sibuk, apalagi jika membandingkan dengan bupati sebelumnya (Wawancara dengan Widya, November 2010). Para birokrat merasa tidak punya kesempatan mencari alternatif lain selain mengikuti ritme kerja Untung. Terlebih lagi, selain begitu padat di setiap bulannya, setiap acara pun terdapat petugas yang bertugas mengabsen. Bupati Untung sendiri selalu mengontrol dan menanyakan jika ada yang tidak hadir. Kegiatan-kegiatan yang diciptakan Untung memang cukup berat, contohnya acara Suling karena pegawai, yang mayoritas bertempat tinggal di Solo, harus berangkat pukul 02.00 pagi (Wawancara dengan Budi S.,16-06-2011).

Bupati Untung Wiyono memiliki visi yang kuat dan ia yakini yaitu, "Birokrasi (pegawai negeri) harus dipaksa, kalau tidak dipaksa tidak akan mau berubah. Walaupun merasa terpaksa itu tidak menjadi soal, namun lama kelamaan akan menjadi biasa dan akhirnya menjadi budaya" (Wawancara dengan Untung Wiyono, 18-082010). Pemaksaan itu pun bukan karena atau dari dirinya, namun karena tuntutan keadaan (masyarakat). Oleh karena itu para birokrat harus tahu dan mau berubah. Itulah strategi politik "memaksa birokrasi berubah dengan memanfaatkan tuntutan masyarakat" yaitu memaksa dan mengubah keadaan dengan menggunakan tangan publik lain.

Menurut Suharno, salah satu pegawai, mereka seperti digiring dan ditarik ibarat serombongan kambing diajak menyeberang sungai. Kambing itu sangat takut dengan air, mereka mau menyeberang jika dipaksa dan ditarik. Meski membelot, tenaga yang menarik lebih kuat sehingga tidak bisa dilawan. Adapula yang telah melihat temannya masuk sungai dan menyeberang sehingga dengan terpaksa mengikuti. Namun demikian, masih ada kambing yang kebingungan dan ragu-ragu di tepi sungai, biasanya yang tertinggal seperti ini jumlahnya sedikit. Jika tuannya kembali dan menarik paksa, kambing ini akan ikut, namun jika tuannya membiarkan maka mereka akan ketinggalan (Wawancara dengan Suharno, 1-08-2010).

Wacana perubahan perizinan kepada para anggota DPRD, pertama kali dilakukan kepada para anggota dewan dari PDIP. Kendaraan politik Untung Wiyono saat mencalonkan diri menjadi bupati adalah PDIP dan Partai Golkar, sehingga tidak ada pertentangan dari PDIP saat wacana tersebut diberitahukan. Di samping itu Untung juga menjabat sebagai Ketua Cabang PDIP Sragen. Sasaran berikutnya adalah anggota dewan dari Partai Golkar yang juga mendukung wacana perubahan perizinan tersebut. Hal ini dikarenakan yang menjabat Ketua Partai Golkar di Sragen adalah wakil bupati Untung, yaitu Agus Fatchurohman. Sedangkan anggota DPRD dari partai lain jumlahnya kurang signifikan, pada periode 1999 anggota DPRD dikuasai oleh PDIP dan Golkar, jumlahnya 33 dari 45 kursi (Sumber: KPU Sragen). Pada saat pemilihan Bupati Sragen tahun 2001, yang dipilih langsung oleh DPRD, pasangan Untung Wiyono dan Agus Fatchurahman memperoleh suara mayoritas yaitu 36 suara, sehingga praktis dukungan anggota DPRD terhadap gagasan inovasi cukup tinggi (Sumber: KPU Sragen).

Demikian juga berbagai stakeholder termasuk masyarakat, mereka sangat mendukung wacana inovasi ini. Terlebih lagi setelah terjadinya reformasi dan demokratisasi, selain berani meminta, masyarakat juga menuntut jika pemerintah daerah lamban dalam mengatasi berbagai hal. Tentu saja masyarakat menginginkan pelayanan prima dari pemerintah daerah. Relasi yang dibangun dalam hal ini adalah relasi kepentingan, dengan menkonfrontasi dan mengonsolidasikan keinginan Untung Wiyono yang sejalan dengan keinginan DPRD dan masyarakat yang menginginkan adanya perubahan, dengan 
birokrasi yang ada dalam dinas dan Satker yang menginginkan status quo.

\section{Mengurai Kebekuan: Strategi Tarik Ulur Kepentingan dalam Kasus E-Government}

Proses unfreezing inovasi e-government terjadi mulai tahun 2002-2004. Tujuan dan kepentingan dari masing-masing aktor terhadap inovasi e-government dalam fase unfreezing tersajikan dalam Tabel 5.

Proses unfreezing dalam inovasi e-government, berdasarkan hasil pembacaan yang oleh Untung Wiyono mengenai kondisi birokrasi dan para birokratnya adalah terikat pada kebiasaan lama yang telah settle, dikenal dengan budaya "alon-alon waton kelakon." Berasal dari bahasa Jawa yang maknanya kurang lebih "biarpun lambat yang penting sampai pada tujuan". Pegawai negeri berbeda dengan pegawai swasta yang selalu diburuburu pekerjaan, deadline, target waktu dan hasil. Pegawai negeri yang rajin dengan yang tidak sama saja penghasilannya. Motivasi menjadi pegawai negeri adalah ingin memperoleh penghasilan tetap dan jelas, tunjangan hari tua yang pasti pula, namun dengan pekerjaan yang longgar tidak diburu-buru (Pandangan ini senada dengan hasil wawancara yang diungkapkan oleh Mahmudi: 18/08/2010, jam 05.30-08.00; Widya : 19/08/2010, jam 09.3012.00; Budi S.: Kamis, 16-06-2011).

Para birokrat telah diuntungkan oleh kondisi yang ada selama ini, sehingga sulit untuk diajak berubah. Terlebih lagi, belum pasti apakah mereka akan memperoleh keuntungan dari kondisi yang baru, karena mereka sudah bosan dengan janji-janji yang seringkali tidak sesuai. Tampaknya sudah ada relasi yang mapan dan terbiasa, antara perilaku kebiasaan yang telah lama dilakukan dengan pemenuhan harapan baik yang bersifat materi maupun ketenangan, tanpa perlu bekerja keras. Tentunya jika bupati mau melakukan inovasi, ia harus bisa membongkar anggapan dan memberikan harapan yang lebih baik. Misalnya bahwa inovasi tersebut akan memberikan keuntungan bagi semua pihak. Oleh karenanya, hal pertama yang harus dilakukan adalah mengurai titik simpul, yang merupakan bentuk relasi yang mengikat

Tabel 5.

\section{Tujuan dan Kepentingan dari Masing-Masing Aktor terhadap Inovasi E-Government dalam Fase Unfreezing}

\begin{tabular}{|c|c|c|}
\hline Aktor & Tujuan & Kepentingan \\
\hline $\begin{array}{l}\text { Bupati (Untung } \\
\text { Wiyono) }\end{array}$ & $\begin{array}{l}\text { Berbagai pihak dapat } \\
\text { menyadari pentingnya } \\
\text { melakukan perubahan sistem } \\
\text { tata kelola birokrasi dengan } \\
\text { berbasis pada teknologi } \\
\text { informasi (IT). }\end{array}$ & $\begin{array}{l}\text { Diakui berhasil membangun Sragen, Untung Wiyono dapat } \\
\text { mengontrol sistem kerja birokrasi dengan mudah dan cepat. Dapat } \\
\text { mengetahui penggunaan keuangan secara cepat, pengambilan } \\
\text { keputusan berdasarkan pada sistem data (decision support system) } \\
\text { atau selalu berbasis pada data yang selalu di-update yang diolah } \\
\text { dan diproses dengan komputer. }\end{array}$ \\
\hline Birokrat & $\begin{array}{l}\text { ja secara nyaman, } \\
\text { cepat }\end{array}$ & Mendapatkan jabatan, insentif, tambahan pendapatan. \\
\hline DPRD & Ikut menumpang popularitas & $\begin{array}{l}\text { Mendapat massa/suara agar dapat terpilih lagi sebagai anggota } \\
\text { DPRD }\end{array}$ \\
\hline Pengusaha & $\begin{array}{l}\text { Proses-proses yg bersentuhan } \\
\text { dengan birokrasi dapat cepat, } \\
\text { mudah, dan murah }\end{array}$ & $\begin{array}{l}\text { Mendapatkan pelayanan yang baik, usahanya lebih lancar. Proses } \\
\text { pengurusan perizinan dan pelayanan yang tidak merugikan } \\
\text { pengusaha. }\end{array}$ \\
\hline $\begin{array}{l}\text { Tokoh } \\
\text { masyarakat, } \\
\text { masyarakat }\end{array}$ & $\begin{array}{l}\text { Sistem regulasi yang lebih } \\
\text { baik }\end{array}$ & $\begin{array}{l}\text { Bupati dan birokrasi dapat melayani masyarakat dengan lebih baik. } \\
\text { Sragen lebih maju, lebih baik, dapat meningkatkan kesejahteraan } \\
\text { masyarakat. Semua informasi tentang daerah dapat dengan mudah } \\
\text { diakses }\end{array}$ \\
\hline $\begin{array}{l}\text { Pemerintah } \\
\text { Pusat }\end{array}$ & $\begin{array}{l}\text { Ditemukan sebuah model } \\
\text { komunikasi yang lebih baik }\end{array}$ & $\begin{array}{l}\text { Daerah dapat melakukan tata kelola pemda yang efektif, efisien, } \\
\text { meningkatkan kesejahteraan masyarakat. }\end{array}$ \\
\hline
\end{tabular}

Sumber: Diolah dari informasi yg diperoleh dari data primer dan sekunder 
mereka, dengan cara memberikan harapan dan kenyataan yang lebih baik.

Sebagai bupati, Untung memiliki kewenangan serta otoritas tertinggi di tingkat lokal, khususnya para birokrat. Sesungguhnya, rencana untuk melakukan reformasi birokrasi dengan melakukan penerapan e-government, dapat ia paksakan kepada para birokrat, kepala dinas, kepala kantor, camat atau yang lain. Hanya saja, karena mereka memiliki kepentingannya masing-masing, Untung harus dapat menjawab pertanyaan mengenai kompensasi yang bisa mereka dapat jika mendukung perubahan. Selain itu, Untung memiliki latar belakang pengusaha di bidang oil and gas yang bermitra dengan Pertamina. Sistem kerjanya sudah terbiasa menggunakan high technology atau komputer, setiap pengambilan keputusan didasarkan pada sistem data (decision support system) atau berbasis pada data yang selalu di-update, diolah, dan diproses dengan komputer dan jaringan (Wawancara dengan Budi S.: Kamis, 16-06-2011).

Untung tampak memahami betul, teknologi bisa memudahkan dalam bekerja namun, untuk pengadaannya tidak mudah dan diperlukan dana yang banyak. Oleh karena itu, di awal masa jabatan periode pertamanya sebagai Bupati Sragen, ia memikirkan jumlah dan dari mana asalnya sumber-sumber keuangan asli daerah, termasuk juga cara untuk menggali sumber-sumber keuangan baru (Wawancara dengan Untung W: 15 Mei 2011). Untung membutuhkan berbagai laporan tentang keuangan dan menghendaki adanya daily report, yang dapat dipantau secara langsung dan cepat. Ia pun ingin mengetahui cash flow keuangan pemerintahan daerah.

Melihat keinginan Untung yang tinggi dan ideal tersebut membuat para stafnya kebingungan. Waktu itu, awal tahun 2001 tidak setiap kantor memiliki komputer, kalaupun ada jumlahnya terbatas, begitu juga kemampuan, itupun bersifat stand alone. Pada waktu itu database dalam komputer sudah ada namun statis karena data diperbaru apabila ada program bersifat proyek. Fungsi komputer waktu itu hanya sekadar untuk menggantikan fungsi mesin ketik manual (Wawancara dengan Budi S.: Kamis, 16-06-2011). Kondisi demikian bagi para pegawai di kota kecil sudah dirasa cukup nyaman.

Sumber daya manusia yang dapat mengoperasikan komputer pun sangat terbatas, yaitu hanya staf administrasi, yang dalam satu kantor jumlahnya hanya satu atau dua orang saja. Pimpinan, mulai dari kepala seksi, kepala bagian, maupun kepala kantor atau kepala dinas selain tidak bisa mengoperasikan juga tidak memahami filosofi cara kerja komputer (Wawancara dengan Budi S.: Kamis, 16-062011). Teknologi sudah menjadi sistem dalam kehidupan manusia baik di rumah, di sekolah, maupun di kantor. Apabila memahaminya sekadar menggantikan fungsi alat lama maka penggunaan komputer tidak optimal dan tidak bisa memanfaatkan secara maksimal. Bahkan kesulitan dan menjadi beban karena harus belajar lagi.

Pegawai negeri tersebut kebanyakan berpandangan, mengapa harus sulit-sulit bekerja dan belajar lagi, apabila tiak ada perbedaan antara yang semangat dengan yang malas. Tidak ada kontraprestasi antara yang rajin dan yang malas, setiap awal bulan tetap akan mendapat gaji (Wawancara dengan Suroso, 17 Juni 2011). Kondisi itulah yang dibaca oleh Untung Wiyono. Berbeda dengan pandangannya yang merasa sangat tidak puas jika membandingkan pengalamannya, yaitu biasa bekerja dengan peralatan teknologi tinggi yang digunakan untuk mempermudah dan menunjang kerjanya.

Kondisi itulah yang menjadi ide dasar Untung untuk membangun Teknologi Informasi dan Komunikasi (TIK) di Kabupaten Sragen. Beberapa kejadian juga menambah keprihatinan Untung dalam menjalankan pemerintahan sehari-harinya, yaitu: 
a. Aparatur bawahannya selalu tidak hadir atau terlambat jika diundang rapat karena terlambat menerima undangan. Sebelum diciptakannya e-government, setiap tahun rata-rata terdaapt 5 undangan yang tidak hadir briefing atau acara pertemuan lain, dengan alasan undangan terlambat. (Sumber: Daftar hadir di Sekretariat).

b. Informasi tertentu sering terlambat.

c. Bupati mengalami kesulitan untuk memperoleh informasi ataupun data secara akurat dan cepat.

d. Bupati mengalami kesulitan jika ingin cepat berkoordinasi dengan aparatur bawahannya.

e. Wilayah pelosok desa medannya sulit untuk ditempuh transportasi.

f. Selain hasilnya belum maksimal, biaya operasional komunikasi seperti menyampaikan informasi atau hasil keputusan, yang memakai surat undangan dan perlu pengiriman ternyata besar sekali, yaitu sekitar 2,3 miliyar dalam setahun (Sumber: Sekretariat Kabupaten Sragen tahun 2010). (Wawancara dengan Untung Wiyono, 20 Agustus 2010)

Berbagai pertimbangan itulah yang menjadi pemicu Bupati Sragen melakukan inovasi di bidang TIK, terlepas dari berbagai alasan lain seperti seringnya pergi ke luar negeri dan mendapati Sragen adalah kota yang tidak dikenal sehingga ia ingin memajukan Kabupaten Sragen dalam masa kepemimpinannya. Adapula alasan lain yaitu putra Untung bersama temannya sering berkomunikasi melalui jaringan internet (Wawancara dengan Bowo anaknya Untung Wiyono, 19 Mei 2011). Alasan lain yang lebih substatif yaitu adanya tuntutan masyarakat yang semakin tinggi dan menyangkut trust, apabila Untung dapat memenuhinya. Trust masyarakat merupakan modal baginya untuk maju menjadi bupati di periode berikutnya.
Untuk melakukan perubahan pelayanan harus didukung oleh efisiensi kinerja birokrasi, yang harus pula dilakukan melalui e-government, yaitu penerapan sistem IT dalam birokrasi. Keinginan semacam itu bagi sebagian pihak mengancam kondisi dan kedudukan para kepala dinas maupun yang lain, karena setiap gerak geriknya termasuk yang menyangkut pembelanjaan keuangan akan mudah terpantau langsung oleh Bupati Untung Wiyono. Tentunya posisi kepala dinas, kepala badan, kepala kantor, camat ini menurut Untung adalah titik simpul yang akan menentukan dalam membangun inovasi.

Inovasi di bidang birokrasi atau e-government melalui penerapan program teknologi informasi dan komunikasi (TIK), jika dilihat secara proses politik relasi kekuasaan berada dalam fase unfreezing. Secara substantif unfreezing yaitu mengubah pandangan dan pola pikir berbagai pihak, khususnya birokrat bahwa inovasi e-government tidak akan merugikan justru menguntungkan, itulah titik temu kepentingan dalam fase ini. Relasi yang dibangun adalah penyadaran atas sikap dan perilaku mereka selama ini. Strategi Untung Wiyono untuk melakukan proses unfreezing adalah dengan membangun mindset yang meliputi membangun kesadaran (awareness raising), menyediakan informasi (providing information), pelatihan (transformation skill), dan memancing atau mendorong semangat (stimulation or encouragement) berbagai pihak dan lebih khusus lagi kepada para birokrat.

Adapun langkah-langkah yang dilakukan adalah selalu mengajak para bawahannya untuk bekerja keras mengabdi dan melayani masyarakat dengan baik (Wawancara dengan Budi S., Mei 2010). Untung selalu menyampaikan ide atau gagasan baru yang kemudian mewujudkan oleh SKPD. Di samping menyampaikan ide baru, bupati juga selalu meminta masukan dan secara terbuka meminta dan mendorong agar bawahannya dapat 
memunculkan ide-ide baru yang inovatif, bahkan melakukan lomba ide kreatif yang dikuti seluruh pegawai negeri berjumlah 13 ribu (Wawancara dengan Tugiyono).

Berbagai kegiatan Bupati tersebut dipublikasikan ke berbagai pihak, sesuai dengan sasarannya dan disiarkan langsung oleh Radio FM milik Pemerintah Daerah Kabupaten Sragen. Bahkan materi-materi pidato dari berbagai acara tersebut telah diterbitkan dalam buku. Untung telah menerbitkan empat buku tentang bermacam ide atau gagasanya yang telah ia sampaikan di berbagai acara. Tiga buku diterbitkan dalam masa jabatan pertama sedangkan satu buku diterbitkan dalam masa jabatan keduanya sebagai Bupati Sragen. Bahan materi atau hasil briefing juga disampaikan kepada seluruh SKPD maupun camat.

Untung Wiyono memahami betul karakteristik budaya birokrasi yaitu patrontclient, sebagaimana diungkap oleh banyak ilmuwan politik (Dwiyanto, 2002, 2003; Thoha, 2002). Para pimpinan seperti kepala dinas, kepala kantor dan camat karena yang mengangkat adalah bupati maka posisi sangat tergantung padanya. Untung sengaja mencari orang-orang yang dekat dengan dirinya agar bisa mendukung ide yang dikeluarkan. Ia membangun relasi simbiosis mutualisme, Untung ingin memperoleh dukungan sedangkan para birokrat ingin memperoleh jabatan atau kedudukan.

Berbagai kegiatan yang dicetuskan Untung merupakan jalinan relasi kekuasaan yang kepada para birokrat karena mereka dipaksa untuk berkerja keras, mengikuti berbagai kegiatan yang frekuensinya sangat padat. Hal ini sebagaimana keyakinan bupati bahwa para pegawai harus dipaksa, walaupun terpaksa lama kelamaan akan terbiasa dan akhirnya menjadi budaya. Itulah bentuk relasi kepentingan yang dibangun oleh Bupati Untung Wiyono dalam mewujudkan berbagai inovasinya, bentuk titik temu kepentingannya bersifat pemaksaan. Relasi yang dibangun didasarkan pada otoritas kewenangan pimpinan kepada bawahan, harus patuh dan taat pada kehendak atasan. Kompensasi yang diberikan selain kedudukan atau jabatan bagi kepala dinas adalah harapan bahwa inovasi e-government akan menjadikan birokrasi lebih baik.

Secara khusus, politik relasi kepentingan yang dilakukan Untung berkenaan dengan inovasi e-government dalam fase unfreezing dikarenakan keinginannya untuk mendapat berbagai data akurat yang menyangkut sumber-sumber keuangan, yang digali oleh SKPD dan meminta adanya daily report. Selain itu juga memudahkan bupati berkomunikasi atau memantau kinerja pegawai. Sehingga proses ini bukan hanya pewacanaan namun pelaksanaan dengan pemaksaan, agar aktivitas para birokrat dapat dikontrol, termasuk aliran pemasukan maupun penggunaan keuangan.

Melihat kondisi birokrasi pemerintahan yang lamban, kurang responsif, kurang produktif serta kinerjanya yang rendah yang berkebalikan dengan kehendak Bupati Sragen yang ingin berbagai data ekonomi yang akurat tersedia dan selalu up to date, maka tidak ada jalan lain selain merombak birokrasi dengan menerapkan TIK. Ide dasar dibangunnya sistem jaringan TIK di Kabupaten Sragen, yang dilakukan oleh Bupati Untung Wiyono pada awal masa jabatannya didasari oleh kebutuhan Untung terhadap berbagai informasi data yang dapat diakses secara cepat dan akurat.

\section{Kesimpulan}

Usaha mempraktikkan kekuasaan dengan menjalin relasi kuasa dengan berbagai pihak, khususnya dalam kajian ini adalah publik atau masyarakat dan birokrasi, dilakukan melalui berbagai cara, di antaranya: 1) Untuk publik dengan cara blusukan turun ke masyarakat, menyampaikan informasi, pengetahuan, mengajak, membujuk dengan memberikan bantuan, meminta dukungan, menyiarkan dan memberitakan; 2) Untuk birokrasi dengan cara 
melakukan pemaksaan, mengikuti jadwal yang sudah ditetapkan, jika tidak mengikuti diberi sanksi, Bupati Sragen memerintahkan para kepala dinas/badan untuk melakukan dialog dan menanggapi pertanyaan dan permintaan masyarakat. Cara-cara ini dilakukan untuk menyadarkan mereka tentang penting dan perlunya perubahan atau inovasi Adapun media atau instrumen yang ia gunakan adalah dengan membuat acara Sarling, Suling, Tarling, Jlajah Deso Milangkori, mendalang, memanfaatkan media radio, televisi, surat kabar seperti koran lokal dan nasional, dan untuk birokrasi ditambah dengan briefing, studi banding, acara senam bersama satu bulan sekali di GOR, dan pengarahan di Pendopo Kabupaten setiap selapanan (35 hari).

Berdasar dua inovasi di atas, penulis menemukan keajegan yang merupakan karakteristik politik inovasi, dalam proses penyadaran (unfreezing) terhadap inovasi kebijakan. Pertama dari sisi aktor, proses penyadaran ini bersifat menyebar. Berbagai pihak terkait mulai dari para tokoh masyarakat, DPRD, pemerintah pusat, pengusaha dan birokrat dapat menerima pemahaman tentang penting dan perlunya inovasi. Namun, resistensi muncul pada kelompok birokrat, karena kepentingan dan eksistensinya terusik. Mereka terbiasa mencari penghasilan tambahan, melalui kebiasaan lama yang dilakukan. Sedangkan inovasi tersebut tidak dapat menjamin tingkat kesejahteraan mereka akan meningkat atau minimal tetap, bahkan bisa berkurang. Para birokrat masih sulit menerima bahwa inovasi kebijakan ini akan memenuhi kepentingannya dan bisa memperbaiki nasibnya.

Kedua, penyadaran pada masingmasing aktor menemui kesulitan manakala pemanfaatan inovasi tidak nampak secara langsung. Misalnya, untuk birokrat yang terkena dampak langsung dari inovasi, akan berbeda dengan kelompok lain yang akan menerima manfaat. Permainan relasi kepentingan antara dua kelompok inilah yang menentukan tingkat kesulitan proses unfreezing. Tuntutan masyarakat terhadap inovasi pelayanan perizinan terpadu sangat tinggi, karena diharapkan banyak memberikan manfaat kepada masyarakat, sebagai pengguna pelayanan. Jika birokrat menolak, maka akan berhadapan dengan tekanan publik. Demikian juga tuntutan terhadap reformasi birokrasi melalui inovasi e-goverment yang cukup tinggi, karena akan memberikan manfaat bagi kedua belah pihak, baik birokrat maupun masyarakat. Proses unfreezing terhadap inovasi pelayanan perizinan terpadu berlangsung selama satu tahun dan e-government selama dua tahun.

\section{Daftar Pustaka}

Ann Glynn, Mary. (1996). Innovative Genius: A Framework for Relating Individual and Organizational Intelligences to Innovation, Reviewed work(s). The Academy of Management Review, Vol. 21, No. 4 (Oct., 1996), pp. 1081-1111. Published by:Academy of ManagementStable URL: http://www.jstor.org/ stable/259165. Accessed: 15/05/2012 10:29

Bains, William. (2009). Leadership and Innovation: How Consensus Management Blocks Genuine Innovation. Editorial published in Bioscience Hypotheses. 2(5) (2009): $277-281$.

Beck.S. dan T. Whistler. (1967). Innovative Organizations: A Selective View of Current Theory and Research. Journal of Business 40:462-9.

Bekkers, Victor J.J.M. (2005). Organizing Innovation: New Approaches to Cultural Change and Intervention in Public Sector Organizations. Publisher IOS Press Nieuwe Hemweg 6B 1013 BG Amsterdam The Netherlands, fax: +31 20687 0019, e-mail: order@iospress.nl

Borins, Sandford. Ed/2008. Innovations in Government: Research, Recognition, and Replication. Ash Institute for Democratic Governance and Innovation, John F. Kennedy School of Government Harvard 
University, Brookings Institution Press Washington, D.C.

Burns, J. MacGregor. (1979). Leadership. Harper \& Row, Publishers, New York.

Budiardjo, Miriam. (1991), Aneka Pemikiran Tentang Kuasa dan Wibawa. Pustaka Sinar Harapan, Jakarta.

Dwiyanto, Agus. (2002), Reformasi Birokrasi Publik di Indonesia. Pusat Studi Kependudukan dan Kebijakan, Universitas Gadjah Mada, Yogyakarta.

Dwiyanto, Agus. (2003). Reformasi Tata Pemerintahan dan Otonomi Daerah. Pusat Studi Kependudukan dan Kebijakan, Universitas Gadjah Mada, Yogyakarta.

Foucault, Michel. (1972). Archeology of Knowledge and Discourse of Language. New York, Pantheon Books.

Foucault, Michel. (1981), The Order of Discourse. London, Routledge \& Keagan Paul.

Freiden, Jeffry. (2000). Modern Political Economy Theory and Latin America Policy. Published USA Westview Pres

Grindle, Merilee S. (1997). Getting Good Government: Capacity Building in the Public Sectors of Developing Countries. Harvard University Press.

Grindle, Merilee S. (2004). Despite The Odds. Princeton University Press.

Hinning. (1963). Planning, Organizing and Managing Change, Good Governance, Training Board. Luton dalam Proceeding Seminar dan Workshop, Terobosan E Inovasi Manajemen Pelayanan Publik, Forum Nasional Untuk Pembaharuan Pemerintah Daerah, Jurusan Ilmu Pemerintahan Fisipol UGM, Yogyakarta, 28-29 September 2005.

Horth, David dan Buchner. (2005). Innovation Leadership: How to Use Innovation to Lead Effectively, Work Collaboratively and Drive Results. Center for Creative Leadership and Continuum, www.dcontinuum.com.

Lewin, Kurt. (1951). Field Theory in Social Science; Selected Theoretical Papers. D.Cartwright (ed.). NewYork: Harper and Row.
Lewin, Kurt. (1973). Group Dynamics and Social Change; Source, Patterns and Consequences by Eva Etzioni Halevy and Amitai Etzioni (eds). New York: Basic Books.

Martin FIMM, John. (1998). Innovation Strategies in Australian Local Government. School of Management Faculty of Business And Associate Australian Housing and Urban Research Institute Faculty of the Built Environment and Engineering Queensland University of Technology.

McHoul, Alec and Wendy Grace. (2002). A Foucault Primer: Discourse, Power and the Subject. Published in the Taylor \& Francis e-Library, New York.

Osborne, Stephen P. \& Kerry Brown. (2005). Managing Change and Innovation in Public Service Organizations. Published by Routledge 270 Madison Ave, New York, NY 10016.

Jawa Pos Pro Otonomi. (2011). Proceeding Seminar dan Workshop: Inovasi Kebijakan Pelayanan Publik Antara Harapan dan Kenyataan. Surabaya, Oktober 2011.

Pelz, D. C. \& F. C. Munson. (1980). A Framework For Organisational Innovating. Unpublished paper, University of Michigan, Ann Arbor.

Pratikno (2004). Dari Good Governance Menuju Just \& Democratic Governance. Makalah pada Seminar Nasional "Governance in Practices: Belajar Dari Pengalaman di Indonesia", yang diselenggarakan oleh Dies Fisipol UGM ke-49.

Pratikno. Ed/2007. Seri Penerbitan Manajemen Jaringan Pemerintahan; Mengelola Dinamika Politik dan Jejaring Kepemerintahan Daerah: Kemitraan, Partisipasi, dan Pelayanan Publik. Program S2 Politik Lokal dan Otonomi Daerah Univ. Gadjah Mada.

Pratikno. (2009). Rekonsilidasi Reformasi Indonesia: Kontribusi Studi Politik dan Pemerintahan dalam Menopang Demokrasi dan Pemerintahan Efektif. Naskah pidato pengukuhan Guru Besar di Fisipol UGM. 
Skogen, Kjell. (2010). Inovasi untuk Inklusi Pengenalan terhadap Proses Perubahan. (http://www.idp-europe.org/indonesia/ buku-inklusi/pdf/17-Inovasi_Inklusi.pdf, download tanggal 19 Januari 2010.)

Skogen, Kjell. (1997). An Introduction to the Process of Innovation. Chapter II in DSSIproject. Socrates Programme 25234-CP-196-NO-ODL. (http://www.uoc.es/ dssi/, 2 Agustus 2012.)

Taufik, Tatang A. (2007). Pengenalan Konsep Sistem Inovasi. Workshop Nasional "Strategi Pengelolaan Keuangan Daerah sebagai Langkah Awal Keberpihakan Pemerintah Daerah terhadap Rakyat Miskin. Yogyakarta, 11 Mei 2007. Jurnal Prospect, Februari 2007, Tahun 3, No. 4.
Thoha, Miftah. (2002). Perspektif Perilaku Birokrasi. PT RajaGrafindo Persada, Jakarta.

Vredenbrug, Jacob. (1986) Metode dan Teknik Penelitian Masyarakat. Gramedia, Jakarta.

Wiyono, Untung. (2008). Menyiasati Hidup dengan Berwirausaha. Penerbit Perusda Percetakan dan Penerbitan Kabupaten Sragen. Cetakan keenam.

Wiyono, Untung. (2010). Meletakkan Pondasi Pembangunan Daerah. Penerbit Perusda Percetakan dan Penerbitan Kabupaten Sragen. Cetakan ketiga.

Wiyono, Untung. (2010). Menjadi Pribadi yang Bermanfaat. Penerbit Perusda Percetakan dan Penerbitan Kabupaten Sragen. Cetakan kelima. 